\title{
The Dismantlement of the Netherlands Antilles: How Autonomy is More Viable than Independence \\ Cameron Wathey
}

Cameron Wathey is from the 37 square mile half-Dutch, half-French island of St. Maarten/St. Martin. His family roots are established on the Dutch side of the island, which is technically considered an autonomous country within the Kingdom of the Netherlands. He is currently studying Cinema Studies, English, and History, with a specific focus on Caribbean History. He is also a student leader on campus, serving as the Vice-President Internal \& Services for the University of Toronto Students' Union. Cameron has a keen interest in the history and culture of the Caribbean, the diaspora, and politics of the region.

On October $10^{\text {th }}, 2010$, the Netherlands Antilles was dismantled. The islands have decided to part ways with Curacao and St. Maarten as countries within the Kingdom of the Netherlands while Bonaire, St. Eustatius, and Saba have become public authorities, the equivalence of municipalities in the Netherlands. The debates over the years pertaining to the viability of the Netherlands Antilles have ended with the Dutch Caribbean achieving their goal. Yet, these islands are not independent territories. They still remain apart of the Kingdom of the Netherlands. This essay addresses the political history that has led to the recent dismantlement of the Netherlands Antilles in which the islands continue to be autonomous partners within the Kingdom of the Netherlands. Due to the recent developments in the dismantlement, however, scholarly work has not been written on the status of the decolonization process as of yet. Therefore, this essay presents the decolonization process up to the final plunge in 2010. Attention will be focused on the context in which the Netherlands Antilles was created, and the key events that have occurred, with the results of 2004 referendum as the culminating event. The idea of autonomy explains why the Dutch territories fought for dissolution yet wanted to remain 'partners' with the Netherland as opposed to independent countries.

For several islands in the Caribbean, the topic of independence does not concern them. A relatively large proportion of non-sovereign islands can still be found in the Caribbean with most being content with the present status of their country. The claim to the acceptance of their relationship with a 'mother country' is mainly due to the evident benefits that are attached with the status of non-sovereignty. Gert Oostindie claims in his article, Dependence 
and Autonomy in Sub-National Island Jurisdictions: The Case of the Kingdom of the Netherlands, that between the collections of islands in the Caribbean, there is a positive correlation between nonsovereignty and standards of living. ${ }^{1}$ According to his findings, Oostindie notes that sovereignty can be a drawback to the economic development. ${ }^{2}$ He notes that the three major countries in the region, Cuba, Haiti, and the Dominican Republic are all sovereign states. In terms of their economic development Haiti is currently the poorest country in the Caribbean with the Dominican Republic tailing right behind. ${ }^{3}$ As for the case of the ten richest islands in the Caribbean, nine of them are non-sovereign. 4 Paul Sutton lists in his article NonIndependent Territories and Small States: Retrospect and Prospect, that non-sovereign territories in the Caribbean also have the advantages of free trade with the metropolis, grants and social welfare assistance, access to foreign capital and labour markets, special tax concessions, aid for infrastructure and communications, a working health care system, high levels of school administration, and relatively low levels of crime compared to their independent counterparts. ${ }^{5}$ Other than the advantages of aid and security by the metropolis, the level of democracy and standards of governance is considerably higher in non-sovereign islands too. The nonindependent islands still attain autonomy, yet standards of governance are defined and enforced by the metropolis. ${ }^{6}$ For all the reasons listed, politicians on non-sovereign islands aspire to maintain their partnership with the metropolis, while at the same time securing maximum autonomy. Godfrey Baldacchino notes that non-sovereign territories, or what he refers to as a 'sub-national island jurisdictions (SNIJ)', are guaranteed a safety net by the metropolitan power, while are granted enough freedom to protect their national identity, local culture, and general exercise of local power. 7 With the dismantlement of the Netherlands Antilles, it was

\footnotetext{
${ }^{1}$ Gert Oostindie, "Dependency and autonomy in sub-national island jurisdictions: The Case of the Kingdom of the Netherlands." The Round Table: The Commonwealth Journal of International Affairs 95, no. 386 (2006): 610.

2 Ibid., 610.

3 Ibid., 610.

4 Ibid., 611.

5 Paul Sutton, “Non-independent Territories and Small States: Retrospect and Prospect" in Governance in the Non-Independent Caribbean: Challenges and Opportunities in the Twenty-First Century, edited by Peter Clegg and Emilio Pantojas-Garcia (Kingston: Ian Randle Publishers, 2009), xxxviii.

6 Oostindie, Dependence and Autonomy in the Kingdom, 611.

7 Godfrey Baldacchino and David Milne, "Success Without Sovereignty: Exploring
} 
not a matter of independence from the Netherlands. Rather it was about securing more autonomous advantages while retaining their relationship with the metropolis.

The historical relationship between the Dutch Caribbean and the Kingdom of the Netherlands indicated the Dutch's neglect for their 'other' colonies in the Atlantic. Like several other European empires, the presence of the Netherlands in the Caribbean dates back to age of colonial expansion in the seventeenth century. While the Dutch acquired six islands in the Atlantic, most of their colonial efforts were devoted towards the Pacific. The West Indies did not appear on the Netherlands' agenda again until World War II. In her famous radio broadcast in 1942, Queen Wilhelmina of the Netherlands announced that after the war, the Kingdom of the Netherlands would pursue a new course. The Queen spoke of 'complete partnership' with and autonomy for the overseas territories. The Queen envisaged solidarity with the overseas territories in which the Dutch government would assist with internal affairs. ${ }^{8}$ This proclamation was a consequence of the growing nationalism in the Dutch East Indies, as well as pressure by the U.S. and England to impose a new approach to colonialism. ${ }^{9}$ The proposal was too late, however, because nationalists in Indonesia declared their independence after the end the war in $1945 .{ }^{10}$ The East Indies was considered a crucial extension to the economy of the Netherlands. The loss of their prized colony in the Pacific suggested that the Dutch were losing their foothold as an empire. Despite their military intervention, however, the Dutch failed to reclaim Indonesia. In 1949, under pressure from the Indonesian independence movement and United States, the Dutch were forced to accept the transfer of sovereignty to the independent Republic of Indonesia. ${ }^{11}$ Traumatized by a violent decolonization, the Dutch were willing to grant more autonomy for their territories in the West.

Sub-National Island Jurisdictions." The Round Table: The Commonwealth Journal of International Affairs 95, no. 386 (2006): 490.

8 Harold Mitchell, Europe in the Caribbean: The Policies of Great Britain, France, and the Netherlands towards their West Indian Territories in the Twentieth Century (Great Britain: University of Edinburgh, 1963), 39.

9 Gert Oostindie and Inge Klinkers, Decolonising the Caribbean: Dutch Policies in a Comparative Perspective (Amsterdam: Amsterdam University Press, 2003), 66. 10 Ibid., 66.

11 Ibid., 67. 
The failure of the Netherlands to reclaim Indonesia benefitted the decolonization of the Netherlands Antilles and Surinam. In an effort to improve their international image after the catastrophic decolonization of Indonesia, the Netherlands were willing to agree to negotiations with the Dutch Caribbean islands. The Caribbean islands had high hopes to acquire the autonomous privileges that were promised by the Kingdom during wartime. The overseas territories did not desire independence, but rather hoped to achieve autonomy while preserving a platonic relationship with the Kingdom. ${ }^{12}$ As for the Netherlands, integrating the colonies into overseas provinces, after the example of the overseas departments of France, was not an option because the Netherlands did not wish to involve the overseas territories in metropolitan affairs. ${ }^{13}$ The result of their round table conferences was the Statuut or the Charter of the Kingdom of the Netherlands in 1954. The Kingdom of the Netherlands was composed of three equal partners: the Netherlands, the Netherlands Antilles, and Suriname.

The Netherlands Antilles and Surinam achieved their goal for autonomy with the Charter. The Charter was designed to grant Surinam and the Netherlands Antilles the rights to self-government while also remain part of the Kingdom of the Netherlands. ${ }^{14}$ The Charter defined foreign affairs, defense, citizenship, and safeguarding proper governmental administration as matters of interest that would be governed by the Kingdom. ${ }^{15}$ With final authority over these affairs, the Netherlands believed that they were ensuring good governance and fundamental human rights in the Netherlands Antilles and Surinam. ${ }^{16}$ Paul Sutton lists that good governance is recognized as having a "broad range of concerns focused on open, transparent and accountable government; efficient, effective and responsive administration; and respect for human rights and law." 17 Good governance for the Netherlands was securing a local government that abided to the framework of democracy. Under the matters that concerned the Kingdom, however, local governments had little power to administer the best interests for their community. The equality promised in the Charter was

\footnotetext{
12 lbid., 74.

13 Mitchell, Europe in the Caribbean, 123.

14 Ibid., 123.

15 Oostindie, Decolonising the Caribbean, 217

16 Ibid., 217.

17 Sutton, Non-Independent Territories, xxxii
} 
unbalanced from the very beginning. The lack of equality created tensions between local governments and the Kingdom's obligation to guarantee good governance. ${ }^{18}$

The Charter functioned as a form of regulation for several years of its instalment until the end of the 1960s. The turning point for the Charter came when violent riots broke out in Curaçao on May 30 1969. It originally began as a labour conflict for higher wages then escalated into racial and political injustice that ended with mass rebellion. Rioters took to the streets and attempted to burn down the capital, Willemstad.19 The Netherlands sent Dutch marines to Curaçao to restore order in the capital of the Netherlands Antilles. While the revolt was quickly terminated, this intervention sparked criticism from the two parties involved. The people of Curaçao considered the military intervention as a form of neo-colonialism while the Netherlands found their political responsibility with the Netherlands Antilles as increasingly problematic. ${ }^{20}$ According to Gert Oostindie in Decolonising the Caribbean, from a Dutch perspective, the Netherlands was caught in a paradoxical situation. The Dutch were obligated to guarantee good governance while at the same time granted the local government the responsibility of overseeing local affairs. ${ }^{21}$ The Netherlands, therefore, believed that they needed to remove themselves from future obligations by dismantling the Netherlands Antilles. ${ }^{22}$

For the Netherlands Antilles political independence was synonymous with economic decline. The economic benefits as part of the Kingdom of the Netherlands made the option of independence unattractive. Aside from the safeguard of good governance, the Netherlands Antilles was provided with development aid from the Netherlands. This aid was used to reduce public debt and finance projects for the development of the infrastructure, with the participation of Dutch companies. ${ }^{23}$ The Netherlands complained that the Netherlands Antilles was too dependent on Dutch economic

\footnotetext{
18 Oostindie, Decolonsing the Caribbean, 218.

19 Rita Giacalone, "The Political Status of Curacao at the End of the Twentieth Century," in Islands at the Crossroads: Politics in the Non-Independent Caribbean, edited by Aaron Gamaliel Ramos and Angel Israel Rivera (Jamaica: Ian Randle Publishers, 2001), 96.

20 Ibid. 96.

21 Oostindie, Decolonising the Caribbean, 99.

22 Ibid., 99.

23 Giacalone, The Political Status, 99.
} 
support and did not produce any revenues in return. ${ }^{24}$ Therefore, the Dutch urged the Netherlands Antilles to pursue political independence however, the other Caribbean territories refused to distance themselves with the Kingdom based on the terms established in the Charter.

After the end of the Curaçao revolt in 1969, the Netherlands attempted to disengage itself from its overseas dependencies. When Surinam proposed their independence to the Dutch, they were met with little resistance. The Dutch recognized Surinam's inevitable independence as an opportunity to distance themselves from their Atlantic territories. ${ }^{25}$ The amount of time between Surinam's proposal for independence to the actual transfer of their independence took only twenty months to come to fruition..$^{26}$ This revealed the Dutch were not willing to gradually assist the Surinamese government, but would rather let them fend for themselves. By 1980, the government of Surinam fell under military dictatorship. ${ }^{27}$ The country was also on the brink of economic ruin. The Netherlands had imposed a 'model decolonization' that would continue to provide development aid, but it was too late. ${ }^{28}$ Even though the military regime has been replaced with a democratic country, Surinam has never recovered from the economic downfall.

Unlike Surinam, the option for political independence for Netherlands Antilles has never been popular. The Dutch attempted to continue to dissociate themselves from the Atlantic after Surinam, but it was not that simple. To dismantle the Kingdom a change to the Charter of 1954 would be needed. To make any changes to the Charter, all partners involved would have to agree. ${ }^{29}$ The Prime Minister of the Netherlands Antilles from 1973 to 1977, Juancho Evertsz, stated in 1975 that independence would be completed under three conditions: first, all six island would have to realize selfgovernment; second, there would need to be a new cooperation between the islands; and finally, the islands will have attained a

\footnotetext{
24 Oostindie, Dependence and Autonomy, 616.

25 Ibid, 617.

26 Ibid., 617.

27 Alma Young, "Decolonization in the Dutch Caribbean: Lessons from the Commonwealth Caribbean" in The Dutch Caribbean: Prospects for Democracy, edited by Betty Sedoc-Dahlberg (New York: Gordon and Breach Science, 1990), 254.

28 Ibid,. 255.

29 Oostindie, Dependence and Autonomy, 616.
} 
reasonable level of economic development before sovereignty began..$^{30}$ Evertsz' requirements for independence emphasized that only when the Netherlands Antilles agreed to these preconditioned terms would the Dutch realize their proposal for the independence of the Netherlands Antilles. With much annoyance to the Dutch, the Netherlands Antilles proved that independence would not be an option.

The Netherlands' hope for the decolonization of the Netherlands Antilles was fading after the disastrous results with Surinam's independence in 1975. The first several years following Surinam's independence the country underwent civil war, economic downturn, a significant lowering of standards of living, and corruption flourished. ${ }^{1}$ Nevertheless, Aruba realized that independence from the Netherlands Antilles might be the only way to achieve complete autonomy. The government of the Netherlands Antilles was composed of a two-tier institutional system: a parliament (Staten) for all the islands and a local government called the island council (eilandsraad). ${ }^{2}$ When the Charter was constructed Curaçao, the largest and most populated island, was granted majority control over the parliament of the Netherlands Antilles. Out of 22 seats for parliament, Curaçao occupied eleven, eight for Aruba, one for Bonaire, and one for the Windward Group (St. Maarten, St. Eustatius, and Saba). 33 Therefore, Curaçao governed the federation's affairs.

In 1977, Aruba had grown tired of living in the shadow of Curaçao's authority. Aruba's decision to secede from the Netherlands Antilles was stemmed from Curaçao's domination as the capital of the federation and along with the discrimination incited by Curaçao. 34 Aruba's struggle for independence could not be achieved without Curaçao's approval. Furthermore, Aruba would also have to acquire approval from the other islands in the Netherlands Antilles,

\footnotetext{
30 Oostindie, Decolonising the Caribbean, 117.

31 Armando Lampe, "The Recolonisation of Aruba," in Islands at the Crossroads:

Politics in the Non-Independent Caribbean, edited by Aaron Gamaliel Ramos and Angel Israel Rivera (Jamaica: Ian Randle Publishers, 2001), 107.

32 Lammert de Jong, "The Implosion of the Netherlands Antilles," in Governance in the Non-Independent Caribbean: Challenges and Opportunities in the TwentyFirst Century, edited by Peter Clegg and Emilio Pantojas-Garcia (Kingston: Ian Randle Publishers, 2009), 28.

33 Young, Lessons, 257.

34 Ibid., 257.
} 
and most importantly, from the Netherlands. After many years of struggle, Betico Croes of the majority party in Aruba finally received cooperation in 1983 from all parties involved. 35 Croes, however, did not bargain for independence. Croes argued for status aparte (separate status), in which Aruba would secede from the Netherlands Antilles in order to manage most of their domestic affairs. ${ }^{36}$ Moreover, Aruba would continue as a partner of the Kingdom of the Netherlands. The Netherlands would only agree to Aruba's status aparte on the condition that Aruba would be compelled to accept independence after ten years. These ten years would serve as a transition period for Aruba to gradually build a stable government and economy before they were deemed independent. 37 Thus, on January 1, 1986, Aruba attained status aparte and was converted into an autonomous partner within the Dutch Kingdom, yet separated from the federation of the Netherlands Antilles. When the time came for their independence in 1996, Aruba succeeded with attaining permanent status aparte within the Kingdom..$^{38}$ Aruba realized that independence would be a risky decision that may or may not end with freedom or the right to self-determination of their government. With the status aparte, Aruba was guaranteed greater autonomy, good governance, economic security from the metropolis, as well as a higher standard of living for its people.

Aruba's secession called for the reconfiguration of the Netherlands Antilles' federal legislature. Until all parties settled upon the restructure of the Netherlands Antilles, the vacant seats in parliament were divided among the remaining five islands. Curaçao solidified their dominance over the central government with fourteen out of twenty fours seats. ${ }^{39}$ Despite being the second largest island in the federation after Aruba's secession as well as the former representative for the Windward Islands in parliament, Sint. Maarten's one seat only increased to three.40 Nonetheless, Sint Maarten was no longer dependent on Curaçao or the central

\footnotetext{
35 Robertico Croes and Lucita Moenir Alam, "Decolonization of Aruba within the Netherlands Antilles," in The Dutch Caribbean: Prospects for Democracy, edited by Betty Sedoc-Dahlberg (New York: Gordon and Breach Science, 1990), 85. 36 Oostindie, Decolonsing the Caribbean, 129.

37 Croes, Decolonization of Aruba, 86.

38 Oostindie, Dependence and Autonomy, 618.

39 Fabian Badejo, "Sint Maarten: the Dutch half in future perspective" in The Dutch Caribbean: Prospects for Democracy, edited by Betty Sedoc-Dahlberg (New York: Gordon and Breach Science, 1990), 128. 40 Ibid., 129.
} 
government at the time of the restructure..$^{41}$ A once a sleepy, uninhabited island with hardly any economic activity has since transformed into an economic superpower within the Caribbean due to extensive investments in the tourist industry..$^{2}$ From the perspective of the politicians on the island, Sint Maarten was already autonomous and self-sufficient. As for the discussion of the Netherlands Antilles, the Netherlands concluded that cutting all ties with their Caribbean islands was no longer a possibility. Instead, the Dutch proposed in 1990 a draft constitution to split the Netherlands Antilles into Curaçao and Bonaire as one country followed by St. Maarten, Saba, and St. Eustatius as the other. 43 The draft constitution was immediately rejected, however. The Dutch went back to the drawing board only to come back three years later to propose status aparte for each island. 44 Political parties in Curaçao strongly pushed for this offer, but as the results of the referendums showed, the people spoke and they preferred to maintain ties with the Netherlands Antilles.45 The idea of dissolution was dismissed once more, for the time being at least.

After a stalemate for the remainder of the twentieth century, Sint Maarten revived debates that have sparked the first step to the dismantlement. 46 The contrasting results of the referendums held in 2004 and 2005 marked the end of the Netherlands Antilles. ${ }^{47}$ With 69 percent, Sint Maarten opted for separate status as an autonomy country within the Kingdom. Curaçao too preferred separate status with 68 percent. Saba and Bonaire's voters preferred for unilateral link with the Netherlands while Stats preferred to maintain the status quo..$^{8}$ The outcome of these results clearly indicated that the Netherlands Antilles was not functioning according to the five islands. Like Aruba, Sint Maarten no longer wanted to take orders from the dominant Curaçao. Ironically, Curaçao wanted to free itself from the burden of its responsibility of overlooking the affairs of Bonaire, Saba, and St. Eustatius. Curaçao wanted to focus on its own

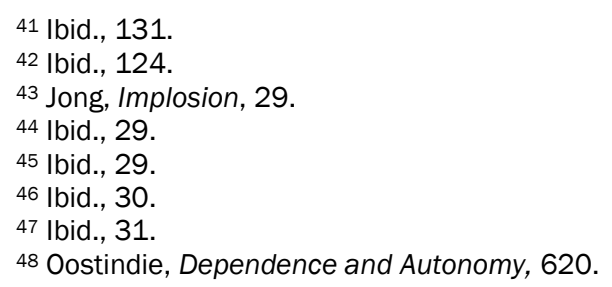


development. 49 On $10-10-10$, the five islands were promised what they voted for.

After fifty years since the configuration of the Kingdom of the Netherlands, the Dutch Caribbean islands were still obsessed with autonomy and refused to completely severe their ties with the Kingdom of the Netherlands. Why would a non-sovereign territory argue for independence when the benefits to autonomy include powers over finance, powers over environmental policy, powers over access, powers over free movements of persons, and powers over tourism policy?50 Curaçao and Sint Maarten are now on the same page as Aruba with high degrees of autonomy. Similarly, the Netherlands has also been relieved of the burden of their larger Caribbean territories. Even though there is no longer a federation that connects the Dutch Caribbean islands, these territories will never completely lose their relationship with the Netherlands. Their relationship within the Kingdom involves a direct connection with the Netherlands, including a Dutch passport, migration to the Netherlands, Dutch protection, and a functioning democracy. ${ }^{51}$ Furthermore, Aruba's status aparte has been a prime example of Curaçao and Sint Maarten should expect. Since their separation, Aruba has performed good governance, and boosted local culture as well as what it means to be an Aruban. As for Sint Maarten, they can continue to improve tourist economy without Curaçao looking over their shoulder. Curaçao too can work on improving and developing their economy as well. The dismantlement of the Netherlands Antilles could very well be the best-case scenario for the smaller islands to improve local conditions with the financial security. The larger, more self-sufficient islands now have the ability to improve their local culture since each island is unique when it comes to the language, race, and environment. The dismantlement of the Netherlands Antilles has granted more autonomy for those who asked for it and a closer relationship to the Netherlands for those who still are dependent on the 'mother country'. These nonsovereign territories seem to have the best of both worlds, but as seen through the history of the Netherlands Antilles, only time can tell if it will remain this way.

\footnotetext{
49 Ibid., 620.

50 Sutton, Non-independent Territories, xxxvii.

51 Oostindie, Decolonising the Caribbean, 221.
} 


\section{Citations}

Badejo, Fabian. "Sint Maarten: the Dutch half in future perspective" in The Dutch Caribbean: Prospects for Democracy, edited by Betty Sedoc Dahlberg, 119-149. New York: Gordon and Breach Science, 1990.

Baldacchino, Godfrey and David Milne, "Success Without Sovereignty: Exploring Sub-National Island Jurisdictions." The Round Table: The Commonwealth Journal of International Affairs 95, no. 386 (2006):490.

Croes, Robertico and Lucita Moenir Alam. "Decolonization of Aruba within the Netherlands Antilles," in The Dutch Caribbean: Prospects for Democracy, edited by Betty Sedoc-Dahlberg, 81-102. New York: Gordon and Breach Science, 1990.

de Jong, Lammert. "The Implosion of the Netherlands Antilles," in Governance in the Non-Independent Caribbean: Challenges and Opportunities in the Twenty-First Century, edited by Peter Clegg and Emilio Pantojas-Garcia, 24-44. Kingston: Ian Randle Publishers, 2009.

Giacalone, Rita. "The Political Status of Curaçao at the End of the Twentieth Century," in Islands at the Crossroads: Politics in the Non Independent Caribbean, edited by Aaron Gamaliel Ramos and Angel Israel Rivera, 95-105. Jamaica: Ian Randle Publishers, 2001, 96.

Lampe, Armando. "The Recolonisation of Aruba," in Islands at the Crossroads: Politics in the Non-Independent Caribbean, edited by Aaron Gamaliel Ramos and Angel Israel Rivera, 106-113. Jamaica: Ian Randle Publishers, 2001.

Mitchell, Harold. Europe in the Caribbean: The Policies of Great Britain, France, and the Netherlands towards their West Indian Territories in the Twentieth Century. Great Britain: University of Edinburgh, 1963.

Oostindie, Gert and Inge Klinkers. Decolonising the Caribbean: Dutch Policies in a Comparative Perspective. Amsterdam: Amsterdam University Press, 2003.

Oostindie, Gert. "Dependency and autonomy in sub-national island jurisdictions: The case of the Kingdom of the Netherlands." The Round Table: The Commonwealth Journal of International Affairs 95, no. 386 (2006) 609-626. 
Paul Sutton, "Introduction: Non-independent Territories and Small States: Retrospect and Prospect" in Governance in the Non Independent Caribbean: Challenges and Opportunities in the Twenty First Century, edited by Peter Clegg and Emilio Pantojas-Garcia, xxiii-xliii. Kingston: Ian Randle Publishers, 2009.

Young, Alma. "Decolonization in the Dutch Caribbean: Lessons from the Commonwealth Caribbean" in The Dutch Caribbean: Prospects for Democracy, edited by Betty Sedoc-Dahlberg, 255-267 New York: Gordon and Breach Science, 1990. 